\title{
Placental Deposition and Transfer of Iron Dextran to Fetuses in Mice at Near Term
}

\author{
Sentaro TAKAHASHI and Osamu MATSUOKA \\ Division of Comparative Radiotoxicology, National Institute of Radiological \\ Sciences, Anagawa 4-9-1, Chiba-shi, Chiba 260, Japan
}

(Received for publication : January 4, 1982)

\begin{abstract}
Deposition of iron dextran particles in the fetoplacental system was investigated by light and electron microscopy after intravenous injection into pregnant mice on days 18-19 of gestation. Thirty minutes after injection, the labyrinth trophoblast cells were strongly positive for iron whereas the fetal capillary endothelium was weakly stained. Electron microscopy revealed the transfer of iron dextran particles to the intercellular space between the first and second layers of trophoblasts, as well as within the vacuoles of the second layer trophoblasts. Transport through the second layer trophoblasts, however, was not evidenced, suggesting that the trophoblast layer may constitute a significant barrier. Three hours after injection, heavy iron reaction was observed in Reichert's membrane, trophoblast cells lined with this membrane, and visceral yolk sac. Electron microscopic examination of parietal yolk sac revealed the aggregation of iron dextran particles in the trophoblast cells with little penetration into the Reichert's membrane and parietal endoderm, suggesting that the Reichert's membrane and adhering trophoblast cells may be a significant barrier for selective transport of particulate materials in the yolk sac placenta.
\end{abstract}

\section{妊娠末期のマウス胎盤における鉄デキストランの \\ 沈着と胎仔への移行について}

高橋千太郎・松 岡 理

放射線医学総合研究所内部被ばく研究部

序文

胎盤は胎仔の維持, 発育に必須の器官であり, そのも っとも重要な機能の一つは，母・胎仔間の物質交換であ る。胎盤におけるイオンやアミノ酸のような低分子物質 の移行に関しては比較的よく検討されているが，高分子 物質や粒子状物質に関しては不明な点も多い[12]。さら に，らさぎ類やげっ歯類においては，絾毛尿膜胎盤以外 に卵黄包葴側板も母仔間物質交換に重要な役割をはたし
ており，ヒトのよらな䋐毛尿膜胎盤が唯一の母仔間物質 移行経路である動物に比べ, 移行経路や選択移行の機序 はより複雑である $[2,5]$ 。

粒子状物質の母仔間移行に関しては, 鉄デキストラン 粒子 $[6], フ ェ リ チ ン[1]$, 脂肪滴 $[11,16]$ な゙の粒子が, ヒトの䋐毛尿膜胎盤を通過することが明らかにされ， ラ ットに拈いても，フェリチンが䄉毛尿膜胎盤と卵黄包胎 盤の両経路で胎仔へ移行することが確認されている $[7$, $8,14]$ 。また， ラットの母血中や子宮粘膜層に投与され た放射性金粒子は，微量ながら胎仔へ移行する $[3,13]$ 
が，二酸化トリウム粒子（トロトラスト）の移行は, ヒ ト[1]拉よびラット $[7,8]$ で否定されており，選択的な移 行が行なわれていると推察されるが，その機序などにつ いては不明な点が多い。

本実験に用いた鉄デキストラン粒子は光顕的に存在が 容易に同定でき，さらに電顕的検討も可能である利点を 有するが, 現在までのところ,げっ苗類における粒子状 物質の経胎盤移行を検討するためのトレーサーとして用 いた報告はない。そこで，著者らは，妊娠末期のマウス 胎盤への鉄デキストラン粒子の沈着様式と, 胎仔への移 行経路について検討し, 従来のフェリチンやトロトラス トをトレーサーとした場合の知見と比較検討した。

\section{材料および方法}

動物：12〜16週齢の $\mathrm{C}_{3} \mathrm{H}$ マウスを用い, 㓐スメア像 で 2 サイクル以上にわたって正常性周期を確 認したの ち, 発情前期に雄と同居させた。翌朝, 交配を胵栓によ り確認し, 妊娠第 1 日とした。妊娠18日に, 鉄デキスト ラン（フェジン，吉富製楽株式会社製）を鉄量として10 〜20mg 尾静脈投与し, 投与後 $1,15,30$ 分および 1,3 ， 6 時間にと殺, 胎仔および胎盤を含む妊娠子宮を摘出し

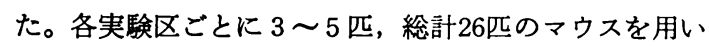
た。

子宮壁に小切開を加えたのち固定, 常法にしたがいパ ラフィン切片を作製, ベルリンブルー反応ケルネヒトロ 一ト染色を施した。電顕用切片は，細切した胎盤を $2 \%$ グルタールアルデヒドで前固定, $2 \%$ 四酸化オスミウム で後固定を行ない，エポン 812 に包埋, Porter-Blum MT-2B 型超ミクロトームで薄切したのち, 酢酸ウラニ ル・クエン酸鉛二重染色を施して, 日立 HU-11B 型電 子顕微鏡を用いて観察した。

\section{成}

静注後 1 分では，鉄デキストランは，䋐毛尿膜胎盤母 血流内にの及凝集して存在し, 栄養膜細胞 ( $\mathrm{T}$ 細胞) p Reichert's 膜 ( $\mathrm{R}$ 膜), 卵黄包臟側板には認められなか った (Fig. 1)。投与後15分では, 栈毛尿膜胎盤迷路部 のT細胞にもわずかながら鉄の反応が認められた。ま た， $\mathrm{R}$ 膜に付着した $\mathrm{T}$ 細胞には，凝集した鉄デキストラ ンを認め, あたかも $\mathrm{R}$ 膜内に拡散するごとき像を呈して いた (Fig. 2)。

投与後30〜60分を経過すると，迷路部の T 細胞には，
比較的強い鉄の反応がみられ, 一部凝集していたが, 胎 仔血管腔周辺の内皮細胞と思われる部位では鉄の反応は 弱く，凝集像はほとんど認められなかった (Fig. 4)。 電顕的には, T細胞第 I ・ II 層の細胞間隙および第 II 層 細胞の空胞内に, 鉄デキストラン粒子の凝集を認めた が， T細胞第而層や，胎仔血管内皮には㥆集粒子はみら れなかった(Fig. 9)。一方, この時期の R 膜に批る鉄 の反応は, 部位によって大きな差があり, 胎盤の周辺部 のR膜においては微弱であったが, 脏带付着部や Duval 内胚葉窩付近は強い鉄反忘を示した (Fig. 3)。

投与後 $3 \sim 6$ 時間では, 迷路部の $\mathrm{T}$ 細胞は, 依然, 鉄 の反応を示し， $\mathrm{R}$ 膜もほぼ全域で強い鉄反応が認められ た (Fig. 6)。さらに, 卵黄包臟側板の内胚葉上皮にも 比較的強い鉄反応が認められ，いわゆる核上部 (supranuclear region) の細胞部分では一部凝集像を示した (Fig. 5)。また, Duval 内胚葉窩付近の T細胞にも鉄 デキストランは非常によく取込まれ，この部位でR膜, 壁側内胚葉, 尿膜内胚葉を経て尿膜循環へ移行する可能 性も示唆された (Fig. 7)。壁側卵黄包の電顕像では, $\mathrm{R}$ 膜に付着した $\mathrm{T}$ 細胞内に電子密度の高い粒子の凝集を 認めたが， R膜内にはまれであった(Fig. 10)。

投与後いずれの時期においても，子宮粘膜の血管内に は鉄反応が認められたが, 粘膜上皮には, 認められなか った (Fig. 8)。

\section{考察}

妊娠末期のげっ歯類における母仔間の物質移行経路 は，䋐毛尿膜胎盤あるいは卵黄包胎盤であるとされてい る [2]が，妊娠後期のマウスでは，鉄デキストラン粒子 は, これらいずれの経路からも胎仔へ移行するものと思 われる。

げっ歯類䋐毛尿膜胎盤迷路部で，母血流と胎仔血流 は, 三層の $\mathrm{T}$ 細胞層, 基底膜, 胎仔血管内皮によって隔 てられている $[4,14,15]$ か，鉄デキストラン投与後 60 分 の観察では，鉄反応は $\mathrm{T}$ 細胞付近で強く，胎仔血管内皮 付近では弱かった。電影的にも，凝集した鉄デキストラ ン粒子は， T細胞第 I， II 層の間隙および第 II 層細胞の 空胞内には認められたが, 第吕層, 基底膜, 胎仔血管内 皮には認められなかった。したがって,この部位での鉄 デキストラン粒子の胎仔移行に関しては，T細胞第 II 層 がバリアーの役割を果し，ここで，鉄デキストラン粒子 は微細粒子化されるか, あるいは可溶性となって胎仔へ 移行することが考觉られる。Tillack [14]む，妊娠ラッ 
トに静注したフェリチン粒子は, 早期に T細胞第II 層に まで達するが, 第而層, 基底膜, 内皮細胞に至るには長 時間を要し, かつ, その量もわずかであることから, フ エリチン粒子の母仔間移行に批いては，T細胞第 II ・ III 層がバリアーであると述べている。

母マウスへの鉄デキストラン静注後 $3 \sim 6$ 時間で, 卵 黄包臓側板の内胚葉上皮にも強い鉄反応が認められ, 卵 黄包胎盤経由の母仔移行が推察されたが，電顕的には， 凝集鉄デキストラン粒子は， $\mathrm{R}$ 膜に付着した $\mathrm{T}$ 細胞内に のみ認められ， $\mathrm{R}$ 膜自体および壁側内胚葉細胞内にはま れであった。したがって， R膜および付着する $\mathrm{T}$ 細胞 が，鉄デキストランの母仔移行に関してバリア一の機能 を有し，ここで, 鉄デキストラン粒子は微細化または可 溶化されたのち, 卵黄包腔へ到達するものと考えられ る。Jollie 5[7,8]は, 妊娠20日齡のラットにトロトラ スト粒子とフェリチン粒子を同時投与し，フェリチンは 容易にR膜を通過して卵黄包臟側板内胚葉上皮にとり込 まれるのに対し，トロトラストは， $\mathrm{R}$ 膜付着 $\mathrm{T}$ 細胞には とり込まれても， R 膜を通過しえないことを報告してい る。

このよらに, 鉄デキストランは, 絨毛尿膜胎盤の母血 流より R 膜とそれに付着する T細胞, 壁側内泼葉を経て 卵黄包腔に移行し, 卵黄包蔵側板内胚葉上皮によって取 込まれるものと思われる。ラットやモルモットにおい て, 卵黄包腔に注入されたフェリチンなどの物質が活発 に臟側板内胚葉上皮にとりこまれ，核上部の細胞質部分 に沈着することが報告されている $[9,10]$ 。一方, 妊娠後 期のげっ歯類においては, 壁側卵黄包の被包部分は開裂 し, 卵黄包腔と子宮腔は一体となっているから, 母血中 の鉄デキストランが卯黄包腔へ到達する経路としては上 記の経路のほか, 子宮粘膜内の母血管から子宮粘膜上 皮, 子宮腔を経て卵黄包腔への経路が考えられる。しか し， Fig. 8 に示すように，鉄デキストラン投与後いず れの時期においても子宮粘膜上皮細胞には鉄反応が認め られなかったので, 鉄デキストランが，この子宮粘膜上 皮を経由して移行することは考えられない。

投与後30〜60分を経過すると，鉄デキストランは，䋐 毛尿膜胎盤と卯黄包の接点, いわゆる Duval 内胚葉窩 付近のT細胞にとくによく取込まれていた。さらに， Fig. 7 に示したよらに, 隣接するR膜, 壁側内胚葉, 尿膜内胚葉にも鉄反応が認められ，鉄デキストランがこ の部位で尿膜循環を経て胎仔へ移行する可能性が示唆さ れたが, げっ歯類でこのような移行経路を示唆した報告 はこれまでのところ見当らない。
以上のごとく, 鉄デキストラン粒子の母血中から胎仔 への移行経路は, 䄉毛尿膜胎盤の迷路部, 䄉毛尿膜胎盤 の母血流から壁側卵黄包, 卵黄包腔を経て卵黄包臓側板 に至る卵黄包胎盤, および Duval 内胚葉窩付近での移 行の三経路が推定されたが，各経路による母仔間移行の 相対的な重要性, 鉄デキストランの移行にともなら物理 化学的変化, 妊娠日令によるバリアーの反応の差などに ついては，今後検討を要する問題である。

\section{要 約}

鉄デキストラン粒子をトレーサーとして，妊娠末期の マウス胎盤への粒子状物質の沈着之胎仔への移行経路に ついて検討した。母体静注後 1 分で，鉄デキストラン粒 子は䄉毛尿膜胎盤の母血流内にのみ凝集して存在し，栄 養膜細胞（ $\mathrm{T}$ 細胞）や Reichert's 膜 ( $\mathrm{R}$ 膜) には認め られなかった。投与後30〜60分で，迷路部の T細胞に強 く, 胎仔血管内皮に弱く鉄反応が認められた。電顕的に も, 第 I , II 層の T細胞間隙や, 第 II 層細胞内に, 鉄デ キストラン粒子を認めたが，第而層から胎仔側には認め られなかった。投与後 $3 \sim 6$ 時間を経ると, 卵黄包臟側 板にも鉄の反忘が認められ，この経路での胎仔移行も示 唆された。電顕的には， R 膜に付着した T細胞内に鉄デ キストラン粒子の凝集がみられたが， $\mathrm{R}$ 膜内には認めら れなかった。また，Duval の内胚葉窩付近のT細胞に む，鉄デキストランは非常によく取り込まれ，この部位 の R膜は強い鉄反応を呈していた。投与後いずれの時期 においても，子宮粘膜の血管内には鉄反応が認められた が，粘膜上皮には認められなかった。

\section{文献}

[1] Ashley, C. A. (1965). Study of the human placenta with the electron microscope. Arch. Path., 80, 377390.

[2] Beaudoin, A. R. (1980). Embryology and Teratology. In The Laboratory Rat, Vol. 2, pp. 75-101, Academic Press, Inc., New York.

[ 3 ] Challier, J. C., and Panigel, M. (1973). Uptake of colloidal ${ }^{198} \mathrm{Au}$ by fetal liver in rat, after direct administration. In. J. Nucl. Med. Biol., 1, 101-109.

[4] Ender, A. C. (1965). A comparetive study of the fine structure of the trophoblast in several hemochorial placentas. Am. J. Anat., 116, 29-68.

[5] 藤原公策 (1972). 母子免疫, その比較生物学, 科学, 42, 114-124.

[6] Hata, T., Amano, K., Kawada, A., Ohkada, K., Aihara, K., Yajima, M., and Uchida, K. (1979). An ultrastructural study on the transfer of iron dextran 
in the chorionic villi of early gestational stage. Acat Obst. Gynaec. Jpn., 31, 208-216.

[7] Jollie, W. P., and Jollie, L. G. (1966). Visualization of transport of electron opaque colloids in placenta membranes of the rat. In Electron Microscopy, Uyeda, R. (editor), Maruzen, Tokyo.

[8] Jollie, W. P. (1968). Changes in the fine structure of the parietal yolk sac of the rat placenta with increasing gestational age. Am. J. Anat., 122, 513532 .

[9] King, B. F., and Enders, A. C. (1970). Protein absorption and trasport by the guinea-pig visceral yolk sac placenta. Am. J. Anat., 129, 262-288.

[10] Lambson, R. O. (1966). An electron microscopic visualization of transport across rat visceral yolk sac. Am. J. Anat., 118, 21-52.

[11] Nakano, M. (1963). Electron microscopic study of the transport mechanism of the human placental villi. Tohoku J. Exper. Med., 78, 398-409.

[12] Schultz, R. L, (1970). Placental transport : A review. Obstet. Gynecol. surv., 25, 979-1020.

[13] Takahashi, S., and Matsuoka, O. (1981). Crossplacental transfer of ${ }^{108} \mathrm{Au}$-colloid in near term rats. J. Radiat. Res., 22, 242-249.

[14] Tillack, T. W. (1966). The transport of ferritin across the placenta of the rat. Lab. Invest., 15, 896909.

[15] Wisloki, G. B., and Dempsey, E. W. (1955). Electron microscopy of the placenta of the rat. Anat. Rec., 23, 33-63.

[16] Yamaguchi, R. Nakano, M., and Sekii, M. (1964). Electron microscopic observations on transference of fat through the human placenta. J. Jap. Obst. \& Gyn. Soc., 11, 151-161.

\section{Explanation of Figures}

\author{
Abbreviations \\ aEn, allantoic endoderm \\ $\mathrm{Bm}$, basement membrane \\ En, fetal endothelium \\ FC, fetal capillary \\ Lab, labyrinth \\ Mbs, maternal blood space \\ $\mathrm{pE}$, parietal endoderm
}

Fig. 1. One minute after iron dextran injection. Iron dextran in the matenal blood space of labyrinth.

Fig. 2. Fifteen minutes after injection. Note heavy iron reaction in the trophoblast cells which are adherent to Reichert's menbrane (arrow).

Fig. 3. Thirty minutes after injection. A strong iron reaction of Reichert's membrane in the central region of chorioallantoic placenta, while slight in the marginal region.

Fig. 4. A portion of labyrinth $60 \mathrm{~min}$. after injection. A strong iron reaction of the trophoblast cells of labyrinth, while weak in the endothelium of fetal capillary (arrow).

Fig. 5. The endodermal cells of visceral yolk sac at $3 \mathrm{hr}$. postinjection. Iron reaction in the supranuclear region of the cells.

Fig. 6. At $3 \mathrm{hr}$. postinjection. Heavy iron reaction in Reichert' smembrane, trophoblast cells which are adherent to this
Rm, Reichert's membrane

Th I, layer I of trophoblast

Th II, layer II of trophoblast

Th III, layer III of trophoblast

vYs, visceral yolk sac

Ysc, yolk sac cavity

membrane, and in visceral yolk sac.

Fig. 7. A portion of Duval's sinus $3 \mathrm{hr}$. after injection. Note the presence of iron reaction in the parietal yolk sac and allantoic endoderm.

Fig. 8. Three hours after injection. A slight iron reaction in the capillary of uterine wall, and no reaction in the uterine epithelium (arrow).

Fig. 9. Electron opaque particles probably of iron dextran in the maternal blood space of labyrinth (large arrow). The particles seem to be transferred to the intercellular space between the layers I and II of trophoblast, and to the channels and vacuoles of the layer II. No iron dextran particles are present in the layer III.

Fig. 10. Electron micrograph of the parietal yolk sac at $6 \mathrm{hr}$. postinjection. Aggregated iron dextran in the trophoblast cells practically without passing into Reichert's membrane. 

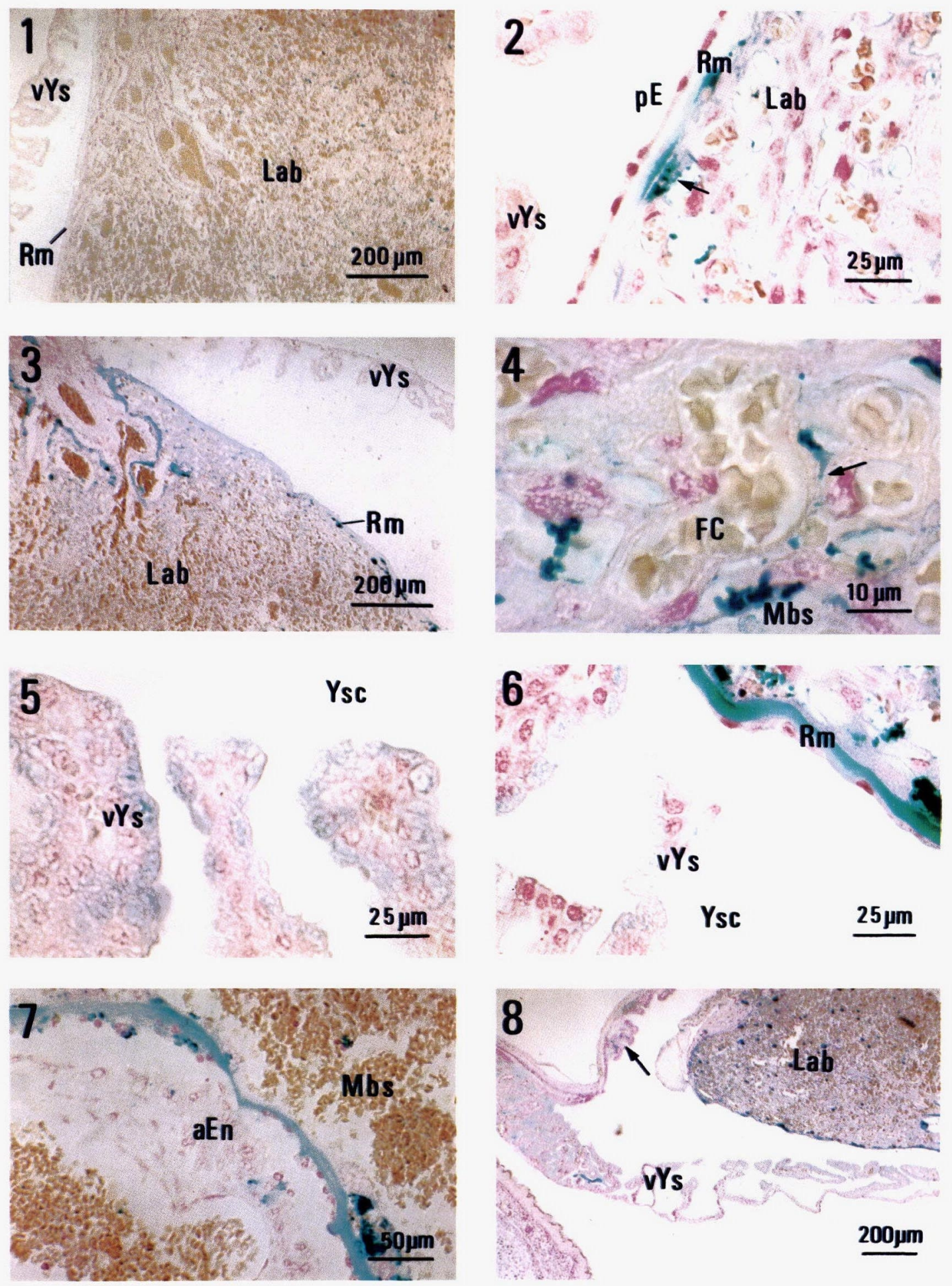

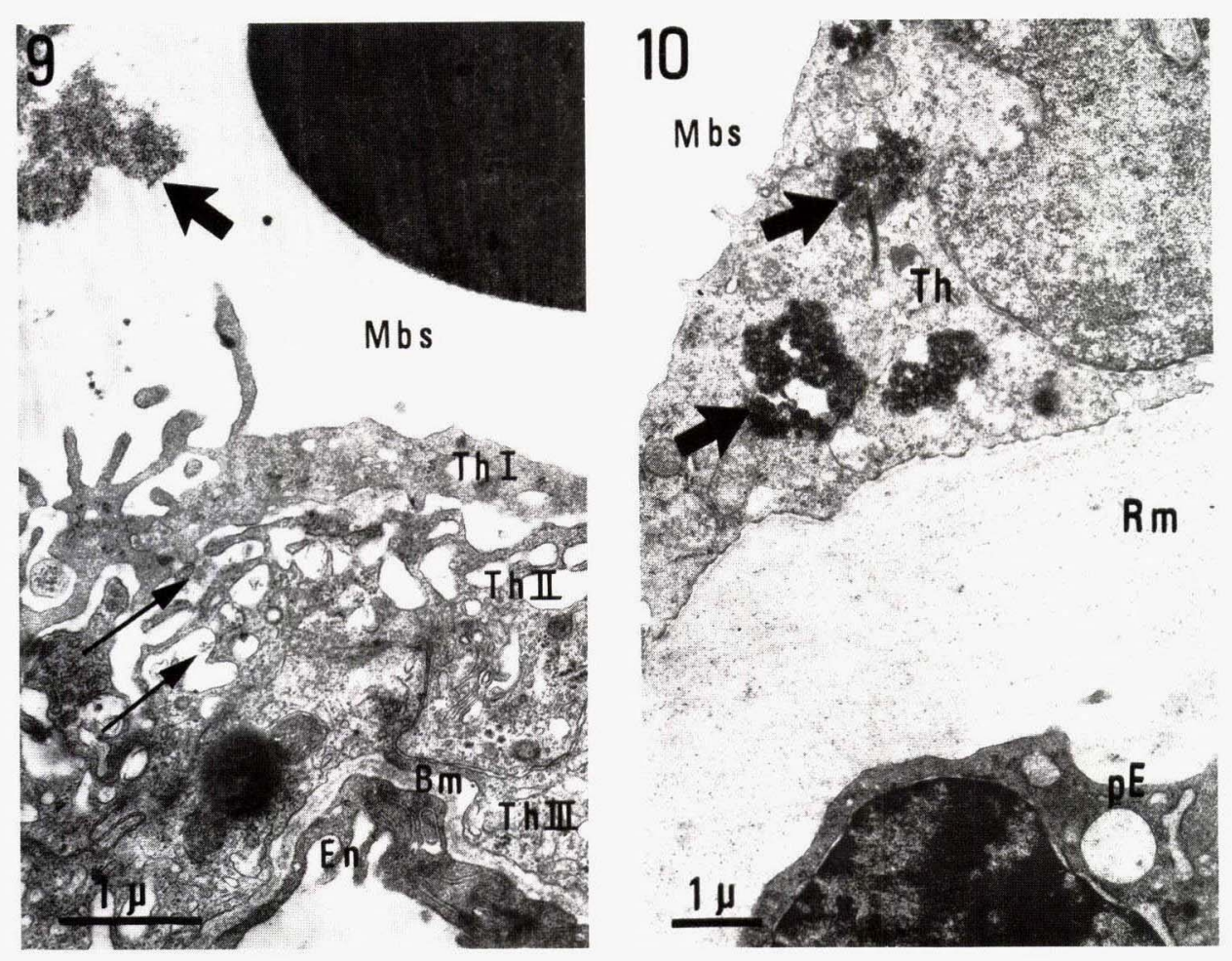